\title{
Dental ankylosis
}

\author{
INSERM
}

\section{Source}

INSERM. (1999). Orphanet: an online rare disease and orphan drug data base. Dental ankylosis. ORPHA:1077

Dental ankylosis is a rare disorder characterized by the fusion of the tooth to the bone, preventing both eruption and orthodontic movement. 